\title{
Psikolojik Sözleşme İhlal Algısının Örgütsel Güven ve Örgütsel Özdeșleşmeye Etkisini Belirlemeye Yönelik Üniversite Çalışanları Üzerinde Bir Araştırma*
}

\section{An Investigation on the Effect of Employees' Perceptions of Psychological Contract Breach on Organizational Trust and Organizational Identification}

\author{
Hacer Koyuncu, ${ }^{\text {a }}$ Ozan Büyükyılmaz ${ }^{\text {b,** }}$ \\ a Bilim Uzmanı, Karabük Üniversitesi, Personel Daire Başkanlığı, 78050, Merkez/Karabük, Türkiye. \\ ORCID: 0000-0002-4614-1269 \\ b Doç. Dr. Karabük Üniversitesi, İşletme Fakültesi, İşletme Bölümü, 78050, Merkez/Karabük, Türkiye. \\ ORCID: 0000-0001-5499-1485
}

\section{MAKALE BİLGİSI \\ Makale Geçmişi: \\ Başvuru tarihi: 22 Ekim 2019 \\ Düzeltme tarihi: 12 Mart 2020 \\ Kabul tarihi: 26 Mart 2020 \\ Anahtar Kelimeler: \\ Psikolojik Sözleşme, \\ Psikolojik Sözleşme İhlali, \\ Örgütsel Güven, \\ Örgütsel Özdeşleşme}

\section{ARTICLE INFO}

Article history:

Received 22 October 2019

Received in revised form 12 March 2020

Accepted 26 March 2020

\section{Keywords:}

Psychological Contract,

Psychological Contract Breach,

Organizational Trust,

Organizational Identification
ÖZ

$\mathrm{Bu}$ araştırma psikolojik sözleşme ihlalinin sonuçlarına odaklanmaktadır. Bu çerçevede psikolojik sözleşme ihlali ile örgütsel güven ve örgütsel özdeşleşme arasındaki ilişkiler araştırılmaktadır. Çalışmanın amacı, çalışanların örgütleriyle arasındaki psikolojik sözleşmede algılanan ihlalin, örgüte karşı hissedilen güven algısını ve örgütle özdeşleşme algısını ne şekilde etkilediğini belirleyebilmektir. Belirlenen amaç için Karabük Üniversitesi'nde idari personel olarak görev yapmakta olan 350 çalışandan anket yoluyla veri toplanmıştır. Araştırma hipotezleri, çoklu doğrusal regresyon analizi ile test edilmiştir. Çalışmanın sonucunda algılanan psikolojik sözleşme ihlalinin örgüte karşı duyulan güveni ve örgütle özdeşleşmeyi olumsuz şekilde etkilediği tespit edilmiştir. Psikolojik sözleşme ihlal algısı, örgütsel güven ve örgütsel özdeşleşme arasındaki ilişkilerin analiz edilmesi ile teoriye ve uygulamaya önemli katkılar sağlanacağı düşünülmektedir.

\section{A B S T R A C T}

This research focuses on the consequences of a psychological contract breach. In this framework, the relationship between psychological contract breach, organizational trust and organizational identification is investigated. The purpose of the study is to determine how psychological contract breach perceived by employees affect perception of trust towards the organization and perception of identification with the organization. For this purpose, data were collected from 350 employees working as administrative staff at Karabuk University. Research hypotheses were tested by multiple linear regression analysis. As a result of the study, it is determined that the perceived psychological contract breach had a negative effect on organizational trust and organizational identification. It is thought that there will be a significant contribution to the theory and practice by analyzing the relationships between the perception of psychological contract breach, organizational trust and organizational identification.

\section{Giriş}

Günümüzde çalışan ve örgüt arasındaki ilişkilerin etkinliğini ortaya koyan ve tarafların yükümlü oldukları sorumlulukları düzenleyen biçimsel sözleşmeler yetersiz kalmaktadır. Çünkü çalışanlar istihdam edildikleri yerlerdeki yasal ve işletme içi yazılı düzenlemelerin yanı sıra kendi içlerinde birtakım beklentilere sahip olabilmekte ve bunu çoğu zaman dile getirmemektedirler. $\mathrm{Bu}$ beklentilerin karşılanması bireyle örgüt arasında güvene dayalı bir ilişkinin sürdürülmesine ve bireyin örgütle özdeşleşmesine neden olabilmektedir. Ancak karşılıklı beklentilerin karşılanmaması durumu örgüte olan güveni

\footnotetext{
*Bu çalışma birinci yazarın 2019 yılında Doç. Dr. Ozan Büyükyılmaz danışmanlığında Karabük Üniversitesi Sosyal Bilimler Enstitüsü İşletme Anabilim Dalı'nda yürüttüğ̈ “Psikolojik Sözleşme İhlalinin Örgütsel Güven ve Özdeşleşme Üzerine Etkisi: KBÜ İdari Personeli Üzerine Bir Uygulama" başlıklı yüksek lisans tezinden türetilmiştir.

** Sorumlu yazar/Corresponding author.

e-posta: ozanbuyukyilmaz@karabuk.edu.tr
} 
azaltmakta ve çalışanların örgütle özdeşleşmesini engelleyebilmektedir.

$\mathrm{Bu}$ kapsamda araştırmada "çalışanların ve örgütlerin birbirlerine karşı olan beklentilerinin karşılanıp karşılanmadığını ifade eden psikolojik sözleşme ihlalinin çalışanların örgütlerine olan güvenlerini ve örgütle özdeşleşmelerini hangi düzeyde etkilemektedir" sorusuna cevap aranmaktadır. Araştırmanın amacı, Karabük Üniversitesi'nde idari personel olarak görev yapmakta olan çalışanların örgütleriyle arasındaki psikolojik sözleşmede algıladığ1 ihlalin örgütüne karşı hissettiği güven algısı ve örgütüyle arasındaki özdeşleşme algısı üzerindeki etkisini belirleyebilmektir.

Karabük üniversitesinde gerçekleştirilen bu çalışmanın üç yönden katkı sağlayacağı düşünülmektedir. İlk olarak, araştırma, ülkemizdeki özel sektör işletmelerinde olduğu kadar kamu kurumlarında da önem kazanan psikolojik sözleşme ihlali, örgütsel güven ve örgütsel özdeşleşme kavramlarını bütüncül bir model çerçevesinde ele alarak literatüre zenginlik kazandırmaktadır. İkinci olarak, bilgi çağında birer öğrenen örgüt olma yolunda çaba gösteren üniversitelerdeki idari personelin önemini ortaya koymaktadır. Üçüncü olarak ise, psikolojik sözleşme ihlali, örgütsel güven ve özdeşleşme kavramlarının bütüncül bir model olarak ele alınması ile üniversitelerde gerçekleştirilen insan kaynakları faaliyetlerine destek sağlanacaktır.

\section{Kavramsal Çerçeve}

Çalışmada psikolojik sözleşme ihlali, örgütsel güven ve örgütsel özdeşleşme kavramlarına odaklanılmakta ve bu üç kavram arasındaki ilişkiler incelenmektedir. Dolayısıyla kavramsal çerçeve içerisinde bu üç kavram tanımlanmaktadır.

\subsection{Psikolojik Sözleşme ve İhlali}

Psikolojik sözleşme kavramının ortaya çıkışı Argyris tarafından 1960 yılında gerçekleştirilen çalışmaya dayanmaktadır. Argyris (1960), psikolojik sözleşme kavramını ilk defa, çalışanlar ile işverenler arasındaki ilişkileri tanımlamak amacıyla kullanmış ve bu kavramı örgüt içerisinde yüksek üretim sağlamak ve sorunları en aza indirgeyebilmek adına; yazılı olmayan, iki taraflı bir sözleşme şeklinde tanımlamıştır. Levinson, ve diğ. (1962) ise kavrama netlik kazandırarak, örgüt ve bireyin birbirlerinden karşılıklı ve yazılı bir dayanağı bulunmayan beklentilerinin toplamı şeklinde ifade etmiştir. Rousseau (1989) da psikolojik sözleşmeye ilişkin karşılıklılık algısını birey seviyesine indirgeyerek çalışanların işle alakalı ilişkileri kapsamındaki karşılıklı yükümlülüklere dair algı ve beklentileri olarak ifade etmiştir. Ayrıca Rousseau (1995) psikolojik sözleşme kavramına, örgüt ile bireyler arasındaki mübadele çerçevesinde örgüt tarafindan şekillendirilmekte olan bireysel inançlar şeklinde de bir tanım getirmiştir.

Psikolojik sözleşme kavramının, örgütsel çevre içerisinde yaşanan hızlı değişim ve gelişimler neticesinde meydana gelen, istihdam ilişkileri ve modern iş hayatını anlayabilmek amacıyla kullanılan bütünleyici bir unsur olduğu söylenebilir (Shore ve Tetrick, 1994; Anderson ve Schalk, 1998; Turnley ve Feldman, 2000). Resmi bir sözleşmeye göre daha öznel, beklentilerin ötesinde geniş kapsamlı bir kavram olan psikolojik sözleşme, çalışanlar ile örgütlerin karşılıklı olarak birbirlerinden ne beklediklerini ve başarı ya da başarısızlıklarının sonuçlarını ortaya çıkaran, açıkça dile getirilmemiş bir anlaşmadır (Cihangiroğlu ve Şahin, 2010; Topcu, 2015). Psikolojik sözleşme en genel tanımıyla işveren ve çalışan arasında olan karşılıklı zorunluluklar ile alakalı inanç ve algıların tümü ve istihdam ilişkisinin temeli şeklinde ifade edilmektedir. Söz konusu olan karşılıklı zorunluluklar, hem çalışanların işverene karşı hem de işverenin çalışanlara karşı yükümlülüklerini kapsamaktadır (Conway ve Briner, 2005:7).

Psikolojik sözleşmeler çerçevesinde örgütün gerekli yükümlülükleri yerine getirmesi, çalışanın örgüte daha fazla bağlılık hissetmesiyle, daha istekli ve fazla çalışmasıyla veya çalışanın tatmin olmasıyla sonuçlanabilmektedir (Büyükyılmaz ve Çakmak, 2014:584). Dolayısıyla çalışan ile örgüt arasındaki etkileşimi güçlendiren ve iş sözleşmeleri dışında gerçekleşen psikolojik sözleşme kavramı giderek daha önemli hale gelmektedir (Çakmak ve diğ., 2012:57). Ancak sözleşme tarafları her zaman için verdikleri vaatleri ve yükümlülüklerini yerine getir(e)memektedir. Yerine getiril(e)meyen vaatler ve yükümlülükler, psikolojik sözleşme ihlali olarak isimlendirilmektedir (Büyükyılmaz ve Çakmak, 2014:584).

Psikolojik sözleşme ihlali, örgüt veya örgüt temsilcilerinin gerçekleştirdikleri katkıya karşılık, bireysel inançlar etrafında gelişen örgütsel yükümlülüklerin yerine getirilmeyişi olarak ifade edilmektedir (Rousseau, 1989:128). Bir başka tanıma göre ise ihlal, çalışanların sözleşme şartlarına dair yükümlülüklerin yerine getirilmediği yönündeki örgütlerinden elde ettikleri bilgi neticesinde meydana gelen tepkisel süreci ifade etmektedir (Shore ve Tetrick, 1994:102). En fazla kullanıldığ biçimiyle psikolojik sözleşme ihlali, kişinin psikolojik sözleşmesi çerçevesinde meydana getirdiği katkılara denk olarak, örgütünün bazı yükümlülüklerini yerine getirmediği şeklindeki inancına ilişkin bilişsel durumdur (Morrison ve Robinson, 1997:230).

Psikolojik sözleşme ihlalinin sonuçlarına ilişkin gerçekleştirilen çok sayıda ampirik çalışma mevcuttur. Bu çalışmalar çerçevesinde, algılanan ihlal sonucunda çalışanın işinden duyduğu tatmin seviyesinde azalma meydana geldiği, örgüte bağlılık seviyesinde bir azalma olduğu, performansında bir azalma meydana geldiği, daha fazla vatandaşlık davranışı sergilemek istemediği ve işinden veya çalıştığı örgütten ayrılmak istediği ortaya konulmaktadır (Büyükyılmaz, 2013:81).

\section{2. Örgütsel Güven}

Araştırmacılar, örgütsel ve yönetsel etkililiğin ön şartı olarak örgüt içerisinde sağlanacak olan güvenin önemine vurgu yapmaktadır. $\mathrm{Bu}$ çerçevede örgütsel güvenin ne olduğuna ilişkin farklı tanımlar bulunmaktadır. Örgütsel güven, örgüt mensuplarının iş tatmini ve algılanan örgüt etkililiğine bağlı olarak, güven iklimi çerçevesinde örgütsel ilişkilere, rollere ve tecrübelere dayanarak örgüt içindeki diğer kişilerin niyetleri ve davranışlarına dair pozitif beklentileridir (Huff ve Kelley, 2003:82). Örgütsel güven, tepe yönetimin çalışanlara desteği, örgüt içi adaletin sağlanması, çalışanların ihtiyaç ve isteklerinin karşılanması, çalışanlar arası işbirliğinin geliştirilmesi, örgüt içindeki 
sosyal ilişkilerin arzu edilen seviyeye çıkarılması hususlarında etkili olmaktadır (Neves ve Caetano, 2006:355). Örgütsel güven bir tanıma göre çalışanların riskli veya belirsiz bir durum karşısında örgütün kendilerine vermiş oldukları taahhüt ve sözleriyle gösterdikleri davranışlar arasında tutarlı olup olmadıklarına ilişkin inançlarıdır. Literatürde ortaya konan tanımlar doğrultusunda örgütsel güven kavramı, "belirli amaçların gerçekleşebilmesi amacıyla örgütsel yapı dâhilinde örgüt üyeleri tarafından birbirlerine yönelik ilişkilerinde inanç, doğruluk, samimiyet, bağlılık gibi değerlerin oluşturulduğu ve oluşturulan bu değerlerin davranışlar ile somutlaştığı bir süreç" şeklinde ifade edilmektedir (Arslan, 2009:274).

Demircan ve Ceylan (2003:142) örgütsel güven kavramını, kültürel temelli, çok düzeyli (çalışma arkadaşları, takımlar, örgüt, örgütler arası), iletişime dayalı, dinamik ve çok boyutlu (duygusal, bilişsel ve davranışsal) şeklinde ifade edilen taraflarına dikkat çekerek tanımlamışlardır. Dolayısıyla örgütsel güven bu özelliği sebebiyle de örgütlere sayısız olumlu çıktı (örgütsel özdeşleşme, çalışan moral ve yaratıcılı, motivasyon, bilgi yaratımı ve yönetimi, örgütsel bağlılık, iletişim, örgütsel verimlilik, çevreye uyum) sağlamaktadır (Üstün, 2015:46). Bu olumlu çıktıların yanı sıra tepe yönetimin çalışanlara ilişkin desteği, örgüt içerisinde adaletin sağlanması, örgüt içerisindeki sosyal ilişkilerin arzu edilen düzeye çıkarılması, çalışanların istek ve ihtiyaçlarının karşılanması da örgütsel güveninin örgütlere olumlu katkıları arasındadır (Neves ve Caetano, 2006:355).

Örgütsel güven, örgütün tüm üyelerinin katılımıyla oluşturulması ve yönetilmesi gereken, kendiliğinden ortaya çıkmayan, psikolojik bir ortamı nitelemektedir. Diğer bir ifade ile örgütsel güven zamanla adım adım oluşturulan ve sürdürülmesi sarf edilen çabaya bağlı olan bir özelliğe sahiptir. Bu nedenle örgütsel güvenin oluşturulmasında ve oluşan güvenin artmasının sağlanmasında etkili olan birçok faktör bulunmaktadır (Şakar, 2010:24-28; Uyar ve Güneş, 2019:122). Bu faktörler literatürdeki çalışmalarda etkili ve açık iletişim, olumlu geri bildirim, örgüt yapısı, katılımcı bir yönetim anlayışı, örgütsel adalet, örgüt kültürü, insan kaynakları yönetimi uygulamaları, personel güçlendirme ve algılanan örgütsel destek olarak ele alınmıştır (Nyhan, 2000; Asunakutlu, 2002; Bijlsma ve Koopman, 2003; Demircan ve Ceylan, 2003; Huang ve Van de Vliert, 2006; Halis ve diğ., 2007; Demirel, 2008; Ristig, 2009; Reychav ve Sharkie, 2010; Li ve diğ., 2012).

\section{3. Örgütsel Özdeşleşme}

Çalışanın kendini örgütle bir görmesi ya da örgüte ait hissetmesi, örgütün başarılı veya başarısız olmasını kendi başarı veya başarısızlığı olarak algılaması şeklinde tanımlanan özdeşleşme, örgütsel davranış alanındaki dikkat çekici araştırma konularından biridir (Mael ve Ashforth, 1992:103). Örgütsel desteğin bir kolu olan bu değişkene ilişkin araştırmaların artırılması örgüt başarısı adına önemli bir konuma sahiptir (Turunç ve Çelik, 2010:184).

Örgütsel davranış yazınında, örgütsel özdeşleşmeye dair ilk çalışma Edward Tolman tarafından 1943 yılında gerçekleştirilmiştir. Tolman örgütsel özdeşleşmeyi çalışmasında, "örgütün geleceği bireyin geleceği, örgütün amacı bireyin amacı, örgütün başarısı bireyin başarısıdır." şeklinde açıklamaktadır (Köse, 2009:2). Dolayısıyla özdeşleşme bütünsel bir kavram niteliği taşımaktadır. Özdeşleşmenin bütünsel bir kavram şeklinde ele alınması da sosyal kimlik teorisinin gelişimi neticesinde ortaya çıkmıştır.

Çalışanların örgüt ile psikolojik bir bağ kurmaları ve kendilerini örgütün bir parçası şeklinde hissetmeleri şeklinde ifade edilen örgütsel özdeşleşme, gerek iyi gerekse kötü günde örgütte kalma arzusu olarak işletmeler tarafından arzulanan pek çok çıktı tutumunun öncülü haline gelmiştir (Turunç ve Çelik, 2010:184). Bir çalışanın örgütsel özdeşleşme seviyesi benliğinin örgüt üyeliğine ne derece bağlı olduğunu göstermektedir. Eğer örgüt üyeliği bireyin benliğinde merkezi bir yere konumlanmış ve onun diğer sosyal gruplardaki üyeliklerinden daha önemli bir konuma gelmiş ise bu kişi örgütle yüksek derecede özdeşleşmiştir (Karabey ve İşcan, 2007:232). Dolayısıyla örgütsel özdeşleşme bireyin, örgüte olan üyeliğinden kaynaklanan bilişsel farkındalığı neticesinde oluşturduğu bilişsel bağ düzeyi, örgütle yüksek derecede duygusal bağ kurması, kendi benliği ile örgütü bütünleştirmesidir (Özan ve Özdemir, 2013:471).

\section{Yöntem}

Yöntem bölümünde araştırmanın hipotezlerine, ana kütleye ve örnekleme, veri toplama ve analiz yöntemine, araştırmada kullanılan ölçeklere yer verilmektedir.

\subsection{Araştırmanın Hipotezleri}

Araştırmalar psikolojik sözleşmeler ile örgüte duyulan güven arasında güçlü bir ilişki olduğunu belirtmektedir (Robinson ve Rousseau, 1994; Robinson ve Morrison, 1995; Robinson, 1996; Deery ve diğ., 2006; Bal ve diğ., 2008; Jafri, 2012). Clinton ve Guest (2014) iki değişken arasında orta derece bir ilişki olduğunu tespit etmiştir $(\mathrm{r}=0,43)$. Yöneticilerin kendi yükümlülüklerini yerine getirdiğine inanması durumunda çalışanlar, yöneticilerin vaatlerine sadık olduklarına inanmakta ve yöneticilerine daha fazla güven duymaktadır. Psikolojik sözleşmede algılanan ihlal ise taraflar arasındaki güven temellerini aşındırmaktadır (Robinson ve Rousseau, 1994; Deery ve diğ., 2006; van Gilst vd diğ., 2020). Dolayısıyla, psikolojik sözleşme ihlalinin çalışanın örgütüne karşı güveninde bir azalmaya neden olduğu düşünülmektedir. $\mathrm{Bu}$ çerçevede, araştırma kapsamında test edilecek ilk hipotez şu şekildedir;

H1: İdari personelin psikolojik sözleşme ihlali algısı örgütsel güven algısını olumsuz yönde etkilemektedir.

Daha önceki çalışmalar, psikolojik sözleşme ihlal algısının çalışan tutum ve davranışları üzerinde olumsuz etkisinin bulunduğunu, bu çerçevede psikolojik sözleşmede algılanan ihlalin çalışanın örgütle arasındaki özdeşleşme derecesini azalttığını göstermektedir (Restubog ve diğ., 2008; Zagenczyk ve diğ., 2013; Yang ve Chao, 2016; Tufan ve Wendt, 2020). Temel olarak araştırmacılar bunun nedeni olarak ihlal algısının çalışanda örgüt için önemsiz olduğu şeklinde bir algı ortaya çıkarması olduğunu belirtmektedir (Restubog ve diğ., 2008). Psikolojik sözleşme ihlali algılaması çalışanın yalnızca kurumuna psikolojik bağlılığını zayıflatmamakta, çalışanın örgüt için ne anlama geldiğini ve örgütün çalışan için ne anlama geldiğini de tekrardan değerlendirmesine neden olmaktadır. Böyle bir süreç özellikle de çalışanın örgüt değerleri nedeniyle kurumu tercih etmesi durumunda çalışan açısından örgütün 
çekiciliğin azalmasına neden olabilmektedir. Dolayısıyla psikolojik sözleşme ihlali çalışanın örgütünü olumsuz olarak görmesine ve kendi değerleri ile örgüt değerleri arasında uyuşmazlık olduğunu algılamasına neden olma olasılığ1 yüksektir (Zagenczyk ve diğ., 2013). Bu çerçevede, araştırma kapsamında test edilecek ikinci hipotez şu şekildedir;

H2: idari personelin psikolojik sözleşme ihlali algısı örgütsel özdeşleşme algısını olumsuz yönde etkilemektedir.

Araştırma hipotezleri kapsamında test edilmek istenen ilişkilerin genel olarak gösterildiği araştırma modeli Şekil 1 'de sunulmaktadir.

Şekil 1. Araştırma Modeli

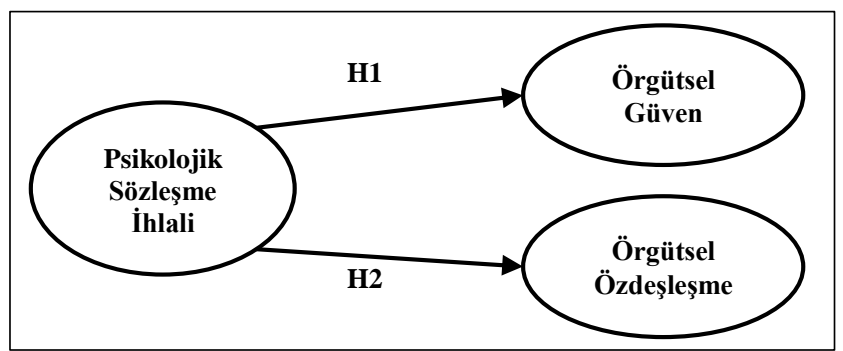

\subsection{Araştırmanın Ana Kütlesi ve Örneklemi}

Araştırmanın ana kütlesi, Karabük Üniversitesi'nde görev yapmakta olan tüm idari personeldir. Karabük Üniversitesi Personel Daire Başkanlığından alınan veriler kapsamında 2018 yılında kurumda toplam çalışan idari personel sayısı 450'dir. $\mathrm{Bu}$ nedenle araştırmanın ana kütlesini 450 idari personel oluşturmaktadır.

450 kişiden oluşan ana kütleyi \%5'lik hata oranı ile temsil eden en küçük örneklem büyüklüğü 210 kişi olarak belirlenmiştir (Sekaran ve Bougie, 2016:263-264). Bu çerçevede kolayda örnekleme yöntemi ile 350 kişinin yüzyüze olarak anketleri doldurması sağlanmış ve örneklem büyüklüğü 350 idari personelden oluşmuştur.

\subsection{Araştırmanın Veri Toplama ve Analiz Yöntemi}

Analizlerde kullanılan verinin elde edilmesinde yüzyüze anket tekniği kullanılmıştır. Bu kapsamda oluşturulan anket formu iki bölümden meydana gelmiştir. İlk bölümde, idari personelin psikolojik sözleşme ihlaline ilişkin algısını belirleyebilmek için 5 ifade, örgütsel güven derecesini belirleyebilmek için 7 ifade ve örgütsel özdeşleşme derecesini belirleyebilmek için 6 ifade bulunmaktadır. Anket formunun ikinci bölümü ise, cinsiyet, medeni durum, yaş, eğitim durumu ve çalışma süresi gibi idari personelin tanımlayıcı özelliklerini belirlemeye yönelik sorulardan oluşmaktadır.

Araştırmada ilk olarak analizler için kullanılan ölçeklerin geçerlilik ve güvenilirlik analizleri yapılmıştır. Ölçeklerin geçerliliği doğrulayıcı faktör analizi, güvenirliliği ise Cronbach Alfa $(\alpha)$ istatistiğinin hesaplanması ile incelenmiştir. Ölçekler için gerçekleştirilen geçerlilik ve güvenilirlik analizlerinin ardından hipotez testleri gerçekleştirilmiştir. Bu kapsamda çoklu doğrusal regresyon analizlerinden faydalanılmıştır. Doğrulayıcı faktör analizi için AMOS programı, güvenilirlik analizleri ve regresyon analizleri için SPSS programı kullanılmıştır.

\subsection{Araştırmada Kullanılan Ölçekler}

Araştırmaya katılan idari personelin örgütüyle arasındaki psikolojik sözleşmede algıladığı ihlalin derecesini tespit edebilmek için Robinson ve Morrison (2000) tarafindan geliştirilen ve 5 ifadeden oluşan ölçekten yararlanılmıştır. Ölçek Büyükyılmaz'ın (2013) çalışmasından adapte edilerek araştırmada kullanılmıştır. Ölçek beşli Likert tipindedir ve tüm ifadelere verilecek cevap kodları 1 ile 5 arasında değişmektedir. Dereceleme maddeleri " 1 Kesinlikle Katılmiyorum, 2-Katılmiyorum, 3- $\mathrm{Ne}$ Katılıyorum Ne Katılmıyorum, 4-Katılıyorum, 5-Kesinlikle Katılıyorum" seçeneklerine sahiptir. Ölçek içerisindeki ilk üç ifadenin skorları ters çevrilerek analizde kullanılmaktadır. Yüksek skorlar, yüksek derecede psikolojik sözleşme ihlali algılandığı anlamına gelmektedir.

Araştırmaya katılan idari personelin örgütüne karşı hissettiği güvenin derecesini tespit edebilmek için Robinson (1996) tarafindan geliștirilen ve 7 ifadeden oluşan ölçekten yararlanılmıştır. Örgütsel güven ölçeğinin Türkçesi Büyükyılmaz ve Fidan (2017) çalışmasından uyarlanarak anket formuna dahil edilmiştir. Ölçek beşli Likert tipindedir ve tüm ifadelere verilecek cevap kodları 1 ile 5 arasında değişmektedir. Dereceleme maddeleri "1-Kesinlikle Katılmiyorum, 2-Katılmıyorum, 3- Ne Katıliyorum $\mathrm{Ne}$ Katılmıyorum, 4-Katılıyorum, 5-Kesinlikle Katılıyorum" seçeneklerine sahiptir. Ölçek içerisindeki üç ifadenin skorları ters çevrilerek analizde kullanılmaktadır. Yüksek skorlar, idari personelin örgütüne karşı yüksek derecede güven algıladığı anlamına gelmektedir.

Araştırmaya katılan idari personelin örgütüyle arasında algıladığ1 özdeşleşmenin derecesini tespit edebilmek için Mael ve Ashforth (1992) tarafindan geliştirilen ve 6 ifadeden oluşan ölçekten yararlanılmıştır. Örgütsel özdeşleşme ölçeğinin Türkçesi Tokgöz ve Seymen (2013) çalışmasından uyarlanarak anket formuna dahil edilmiştir. Ölçek beşli Likert tipindedir ve tüm ifadelere verilecek cevap kodları 1 ile 5 arasında değişmektedir. Dereceleme maddeleri "1-Kesinlikle Katılmıyorum, 2-Katılmıyorum, 3$\mathrm{Ne}$ Katılıyorum $\mathrm{Ne}$ Katılmiyorum, 4-Katılıyorum, 5Kesinlikle Katıliyorum" seçeneklerine sahiptir. Yüksek skorlar, idari personelin örgütüyle arasında yüksek derecede özdeşleşme algıladığı anlamına gelmektedir.

\section{Bulgular}

Bulgular kapsamında öncelikle katılımcıların demografik özellikleri incelenmekte, daha sonra sırasıyla geçerlilik analizine, güvenilirlik analizine ve hipotez testlerine ilişkin sonuçlara yer verilmektedir.

\subsection{Katılımcıların Demografik Özellikleri}

Araştırmaya katılan idari personelin demografik özellikleri kapsamında cinsiyet, medeni durum, yaş, eğitim durumu ve çalışma süresi incelenmektedir. Katılımcıların demografik özelliklerine göre dağılımı Tablo 1'de sunulmaktadır. 
Tablo 1. Katılımcıların Demografik Dağılımı

\begin{tabular}{lcc}
\hline Değişken & Frekans (N) & Yüzde (\%) \\
\hline Cinsiyet & 147 & \\
Kadın & 203 & 42,0 \\
Erkek & & 58,0 \\
Eğitim Durumu & 39 & \\
Lise ve Altı & 99 & 11,2 \\
Önlisans & 165 & 28,3 \\
lisans & 47 & 47,1 \\
Lisansüstü & & 13,4 \\
Çalışma Süresi & 66 & \\
0-1 Y11 & 97 & 18,9 \\
2-5 Y11 & 101 & 27,7 \\
6-10 Y1 & 86 & 28,9 \\
10 Y1ldan Fazla & & 24,5 \\
Medeni Durum & 125 & \\
Evli & 225 & 35,7 \\
Bekar & & 64,3 \\
Yaș & 76 & \\
30 yaş ve altı & 174 & 21,7 \\
31-40 yaş arası & 91 & 49,7 \\
41-50 yaş arası & 9 & 26,0 \\
51 yaş ve üstü & 350 & 2,6 \\
TOPLAM & & 100 \\
\hline
\end{tabular}

Tablo 1'e göre katılımcıların \%58'i erkek ve \%42'si kadın, $\%$ 64,3'ü bekar ve \%35,7'si evli personelden oluşmaktadır. $\mathrm{Bu}$ çerçevede katılımcıların çoğunluğunun erkek ve yine çoğunluğunun bekar olduğu görülmektedir. Eğitim durumuna göre dağılım incelendiğinde katılımcıların $\% 11,2$ 'sinin lise ve alt1, \%28,3'ünün önlinsans, \%47,1'inin lisans ve \%13,4'ünün lisansüstü derecesine sahip olduğu görülmektedir. Dolayısıyla araştırmaya katılan idari personelin çoğunluğu lisans derecesine sahiptir. Katılımcıların yaș dağılımına bakıldığında, \%21,7'si 30 yaş ve altı, \%49,7'si 31-40 yaş arası, \%26,0'sı 41-50 yaş arası ve $\%, 2,6$ 's1 51 yaş ve üstü çalışanlardan oluşmaktadır. Bu kapsamda araştırmaya daha çok 31-40 yaş arası çalışanların katılım sağladığı görülmektedir. Son olarak çalışma süresi açısından örneklem incelendiğinde, katılımcıların $\% 18,9$ 'unun 1 yıl ve daha az süredir, $\% 27,7$ 'sinin $2-5$ yıldır, \%28,9'unun 6-10 yıldır ve \%24,5'inin 10 y1ldan fazla süredir kurumunda çalıştığ görülmektedir. Bu çerçevede çalışma süresi açısından örneklem içerisindeki dağılımın eşite yakın olduu görülmektedir.

\subsection{Doğrulayıc1 Faktör Analizi}

Çalışma kapsamında analizlerde kullanılan psikolojik sözleşme ihlali ölçeği, örgütsel güven ölçeği ve örgütsel özdeşleşme ölçeği farklı araştırmalardan alınarak araştırmada kullanılmaktadır. $\mathrm{Bu}$ nedenle, belirtilen ölçeklerin yapısal olarak geçerli olup olmadığını belirlemek amacıyla doğrulayıcı faktör analizinden faydalanılmıştır. $\mathrm{Bu}$ amaçla, psikolojik sözleşme ihlali ölçeğinin, örgütsel güven ölçeğinin ve örgütsel özdeşleşme ölçeğinin birlikte dahil edildiği bir ölçüm modeli oluşturulmuştur. Ölçüm modeli içerisinde, örgütsel güven ölçeğindeki bir ifadenin (çalıştığım kurumdaki yöneticilere tam anlamıyla güvenmiyorum) ve örgütsel özdeşleşme ölçeğindeki bir ifadenin (başkalarının çalıştığım kurum hakkındaki düşünceleri benim için önemlidir) 0,50'nin altında faktör yüküne sahip olduğu belirlenmiştir. Hair ve diğ. (2014:115) faktör analizi sonucunda 0,50 'nin altında faktör yüküne sahip olan ifadelerin analiz dışına atılması gerektiğini ve analizin tekrarlanması gerektiğini belirtmektedir. $\mathrm{Bu}$ çerçevede belirtilen iki ifade analiz dıșında bırakılmış ve doğrulayıcı faktör analizi tekrarlanmıştır.

Analiz sonucunda psikolojik sözleşme ihlali ölçeği içerisindeki ifadelere ilişkin en düşük t-değeri 9,758, örgütsel güven ölçeği içerisindeki ifadelere ilişkin en düşük t-değeri 9,558 ve örgütsel özdeşleşme ölçeği içerisindeki ifadelere ilişkin en düşük $t$-değeri 9,545 olarak hesaplanmıştır. Ayrıca faktör yükleri incelendiğinde, psikolojik sözleşme ihlali ölçeği faktör yükleri 0,517-0,861 arasında, örgütsel güven ölçeği faktör yükleri 0,511-0,900 arasında ve örgütsel özdeşleşme ölçeği faktör yükleri 0,516-0,889 arasında değişmektedir. Dolayısıyla tüm faktör yükleri 0,50'nin üzerindedir ve 0,01 seviyesinde anlamlıdır (Hair ve diğ., 2014:115).

Doğrulayıcı faktör analizi kapsamında ölçüm modelinin genel olarak kabul edilebilmesi bazı uyum iyiliği değerlerinin istenen değerleri alması ile gerçekleşmektedir. $\mathrm{Bu}$ kapsamda model uyumu ki kare uyum testi $(\chi 2 / \mathrm{sd})$, uyum iyiliği indeksi (GFI), normlandırılmış uyum indeksi (NFI), Tucker-Lewis indeksi (TLI), karşılaştırmalı uyum indeksi (CFI) ve yaklaşık hataların ortalama karekökü (RMSEA) ile test edilmektedir. Model uyumu sağlanabilmesi için $\chi^{2} / \mathrm{sd}$ değerinin 5'den küçük olması, GFI değerinin 0,85 'den büyük olması, NFI, TLI ve CFI değerlerinin 0,90'dan büyük olması ve RMSEA değerinin 0,80'den küçük olması gerekmektedir (Byrne, 2016:90-102; Kline, 2016:265-280; Meydan ve Şeşen, 2011:31-37; Schumacker ve Lomax, 2010:85-89). Doğrulayıcı faktör analizi ile elde edilen uyum iyiliği değerleri incelendiğinde, tüm değerlerin istenilen sınırlar içerisinde olduğu belirlenmiştir $\quad(\chi 2 / \mathrm{sd}=2,173, \quad \mathrm{GFI}=0,936, \quad \mathrm{NFI}=0,949$, TLI=0,965, CFI=0,972, RMSEA=0,058). Bu kapsamda, 5 ifadeli psikolojik sözleşme ihlali ölçeği, 6 ifadeli örgütsel güven ölçeği ve 5 ifadeli örgütsel özdeşleşme ölçeği için yapı geçerliliği sağlanmıştır.

\subsection{Güvenilirlik Analizi}

Araștırma kapsamında kullanılan ölçeklerin yap1 geçerliliğinin sonrasında güvenilirlikleri belirlenmiștir. Güvenirlik, katılımcıların ifadelere verdikleri cevaplar arasındaki tutarlılık şeklinde tanımlanmaktadır (Büyüköztürk, 2016:180-181). Güvenirlik analizi konusunda yaygın olarak kullanılan teknik, 0,00 ila 1,00 arasında değişen Cronbach's Alpha istatistiğinin hesaplanmasıdır. $\mathrm{Bu}$ çerçevede ölçeklere ilişkin güvenilirlik, ölçeklerin Cronbach's Alpha $(\alpha)$ istatistiği hesaplanarak tespit edilmiştir. Genel olarak bir ölçüm aracının güvenilir kabul edilebilmesi için Cronbach's Alpha istatistiğinin 0,70 veya üzerinde olması beklenmektedir (Nunnally ve Bernstein, 1994:265). Araştırmada kullanılan ölçeklere ilişkin hesaplanan Cronbach Alfa değerleri incelendiğinde, psikolojik sözleşme ihlali ölçeği için güvenilirlik 0,861 , örgütsel güven ölçeği için güvenilirlik 0,908 ve örgütsel özdeşleşme ölçeği için güvenilirlik 0,865 olarak hesaplanmıştır. Elde edilen bulgular, tüm ölçekler için hesaplanan güvenilirlik değerlerinin 0,70 'in üzerine olduğunu ve dolayısıyla araştırmada kullanılan ölçekler için güvenilirliğin sağlandığını göstermektedir (Nunnally ve Bernstein, 1994:265).

\subsection{Hipotez Testleri}

$\mathrm{Bu}$ çalışmanın amacı, Karabük Üniversitesi'nde idari personel olarak çalışmakta olan kişilerin örgütleriyle 
arasındaki psikolojik sözleşmede algıladıkları ihlalin, örgütlerine karşı hissettikleri güveni ve örgütleriyle kendilerini özdeşleşme derecesini nasıl etkilediğini belirleyebilmektir. $\mathrm{Bu}$ amaçla, psikolojik sözleşmede algılanan ihlalin örgütsel güven üzerindeki etkisini ve psikolojik sözleşmede algılanan ihlalin örgütsel özdeşleşme üzerindeki etkisini tespit edebilmek için iki ayrı regresyon modeli kurulmuştur. Modelde, demografik değişkenler (cinsiyet, medeni durum, yaş, eğitim durumu, çalışma süresi) kontrol değișkeni olarak kullanılmıștır.

İdari personelin örgütüyle arasındaki psikolojik sözleşme ihlaline ilişkin algısının örgütüne karşı hissettiği güven üzerindeki etkisini test edebilmek amacıyla oluşturulan regresyon modeli sonuçları Tablo 2'de sunulmaktadır.

Tablo 2. Psikolojik Sözleşme İhlali - Örgütsel Güven İlişkisi

\begin{tabular}{lc}
\hline Bağımsız Değişkenler & Bağımlı Değişken \\
\hline Kontrol Değişkenleri & Örgütsel Güven \\
Cinsiyet & $-0,047$ \\
Medeni Durum & $-0,107^{*}$ \\
Yaş & 0,038 \\
Eğitim Durumu & 0,030 \\
Çalışma Süresi & 0,045 \\
Bağımsız Değişken & \\
Psikolojik Sözleşme İhlali & $-0,291^{* *}$ \\
\hline F Değeri & $6,321^{* *}$ \\
R2 & 0,100 \\
Düzeltilmiş R2 & 0,084 \\
\hline
\end{tabular}

${ }^{*} \mathrm{p}<0,05 ; * * \mathrm{p}<0,01 ; \mathrm{N}=350$

Araştırmada ilk hipotez, psikolojik sözleşme ihlal algısı ile örgütsel güven arasındaki ilişkiye odaklanmaktadır. Gerçekleștirilen regresyon analizi sonucunda psikolojik sözleşme ihlal algısının örgütsel güven üzerinde olumsuz yönde etkisinin bulunduğunu göstermektedir $(\mathrm{H} 1: \beta=-$ $0,291, \mathrm{p}<0,01)$. Elde edilen bulgu, idari personelin örgütüyle arasındaki psikolojik sözleşmede algıladığı ihlalin artması durumunda örgüte karşı hissedilen güven derecesinin azaldığını göstermektedir. Dolayısıyla, "idari personelin psikolojik sözleşme ihlali algısı örgütsel güven algısını olumsuz yönde etkilemektedir" şeklinde oluşturulan H1 hipotezi kabul edilmiştir.

İdari personelin örgütüyle arasındaki psikolojik sözleşme ihlaline ilişkin algısının örgütüyle arasında algıladığg özdeşleşme üzerindeki etkisini test edebilmek amacıyla oluşturulan regresyon modeli sonuçları Tablo 3'de sunulmaktadir.

Tablo 3. Psikolojik Sözleşme İhlali - Örgütsel Özdeşleşme İlişkisi

\begin{tabular}{lc}
\hline Bağımsız Değişkenler & Bağımlı Değişken \\
Kontrol Değişkenleri & Örgütsel Özdeşleşme \\
Cinsiyet & 0,012 \\
Medeni Durum & $-0,137^{*}$ \\
Yaş & $0,108^{*}$ \\
Eğitim Durumu & $0,106^{*}$ \\
Çalışma Süresi & $-0,037$ \\
Bağımsız Değişken & \\
Psikolojik Sözleşme İhlali & $-0,286^{* *}$ \\
\hline F Değeri & $8,630^{* *}$ \\
R2 & 0,131 \\
Düzeltilmiş R2 & 0,116 \\
\hline
\end{tabular}

$* \mathrm{p}<0,05 ; * * \mathrm{p}<0,01 ; \mathrm{N}=350$
Araştırmada ikinci hipotez, psikolojik sözleşme ihlal algısı ile örgütsel özdeşleşme arasındaki ilişkiye odaklanmaktadır. Gerçekleştirilen regresyon analizi sonucunda psikolojik sözleşme ihlal algısının örgütsel özdeşleşme üzerinde olumsuz yönde etkisinin bulunduğunu göstermektedir $(\mathrm{H} 1: \beta=-0,286, \mathrm{p}<0,01)$. Elde edilen bulgu, idari personelin örgütüyle arasındaki psikolojik sözleşmede algıladığı ihlalin artması durumunda örgütüyle arasında algıladığ1 özdeşleşme derecesinin azaldığını göstermektedir. Dolayısıyla, “idari personelin psikolojik sözleşme ihlali algısı örgütsel özdeşleşme algısını olumsuz yönde etkilemektedir" şeklinde oluşturulan $\mathrm{H} 2$ hipotezi kabul edilmiştir.

\section{Sonuç ve Öneriler}

Kurumlar, insanlar gibi yaşayan karmaşık yapılar olup birbirleriyle sürekli bir etkileşim içerisindedirler. Dolayısıyla bu ilişkinin sürdürülebilir olması, yöneticilerin çalışanlarla kurdukları psikolojik sözleşmenin varlığına bağlıdır. Çünkü psikolojik sözleşme kavramı, kurum içinde meydana gelen çatışmaları, işe devamsızlıkları, personel devir hızını ve iş tatminsizliğini ortadan kaldıran örgütsel güven ve örgütsel özdeşleșme açısından büyük önem taşımaktadır. $\mathrm{Bu}$ önemden hareketle Karabük Üniversitesinde çalışan idari personel üzerinde bir alan çalışması gerçekleştirilmiştir.

Yıldız ve Aykanat (2017), çalışanların verimli bir biçimde çalışıp çalışmadıklarını, kurumlarını destekleyip desteklemediklerini iki temel neden bağlamaktadırlar. Bunlar; kurum ve birey beklentilerinin karşılıklı olarak yerine getirilme derecesi ve karşılıklı değişimde bulunulan konuların özellikleridir. Ancak araştırmada idari personelin, üniversiteye sağladıkları katkılara karşılık olarak vaat edilen her şeyi tam alamadıkları ve çalıştıkları süre boyunca verilen vaatlerin başarıyla tam olarak yerine getirilmediğini düşündükleri tespit edilmiştir. İdari personel, işe başladıklarında kendilerine verilen sözlerin bazılarının yerine getirildiğini ve psikolojik sözleşme algılarının orta düzeyde olduğu söylenebilir. Kurumlarda çalışanların psikolojik sözleşmedeki ihlali algılama düzeylerinin yüksek olması, verimliliği etkileyecek işyeri davranışlarına neden olduğu çeşitli çalışmalarda ortaya konulmuştur (Robinson, 1996; Morrison ve Robinson, 1997; Kickul, 2001). Bu açıdan özelde Karabük Üniversitesinde, genelde ise tüm kurumlarda çalışan kişilerin gelişimine destek olunarak, terfi gibi imkânlar sağlanarak, kuruma bağlılıkları arttırılarak ve tatminleri sağlanarak sınırları belli olmayan psikolojik ilişkilerin güçlendirilmesi zorunluluk arz etmektedir.

Bilgi çağında hızla değișen iş ilișkilerinde dikkat çeken konulardan biri, kurum yöneticilerinin başarısız ve hatalı uygulamaları nedeniyle yaşanan örgütsel sorunlardır. Dolayısıyla bu sorunlar çalışanlarda tedirginlik, kuşku, yabancılaşma ve en önemlisi güvensizlik yaratmaktadır. Bu kapsamda çalışmada; katılımcıların çoğu kurumdaki yöneticilerin kendilerine karşı nispeten açık ve samimi olduklarını, nispeten güvenilir ve iyi niyetli olduklarını düşünmektedirler. Katılımcıların, kurumdaki yöneticilerin her zaman açık sözlü ve dürüst oldukları konusunda ve kendilerine adil davranmaları konusunda bir kararsızlık yaşadıkları tespit edilmiştir. Ayrıca idari personelin, yöneticilerden tutarlı ve öngörülebilir bir şekilde davranmalarını bekledikleri ortaya çıkmıştır. Bu 
sonuçlardan hareketle idari personelin güvenle ilgili düşüncelerinin orta düzeyde olduğu söylenebilir. Çalışanların yönetime karşı şüpheci olmaları ve çalışanlara yeteri düzeyde değer verilmediğine yönelik inançları, kuruma olan güvenlerinin azalmasina neden olabileceği gibi kurumsal itibarı da tehlikeye düşürebilecek sonuçlar doğurabileceği düşünülmektedir.

Bir çalışanın örgütsel özdeşleşme seviyesi benliğinin kurum üyeliğine ne derece bağlı olduğunu göstermektedir. Eğer kurum üyeliği bireyin benliğinde merkezi bir yere konumlanmış ve onun diğer sosyal gruplardaki üyeliklerinden daha önemli bir konuma gelmiş ise bu kişi kurumla yüksek derecede özdeşleşmiş demektir (Karabey ve İşcan, 2007:232; Turunç ve Çelik, 2010:184; Özan ve Özdemir, 2013:471). Bu çerçevede Karabük Üniversitesi idari personelinin, çalıştıkları kurumun eleştirilmesi ve medyada kurumla ilgili kötü bir haberin çıkması durumunda nispeten üzüntü duymakla birlikte kurumun övülmesi durumunda da nispeten gurur duyduklarını ifade ettikleri görülmektedir. İdari personelin her zaman olmasa da çalıştıkları kurumdan bahsederken, "onlar" değil, "biz" diye ettiklerini ve kurumun başarısını kendi başarıları gibi gördüklerini ifade etmişlerdir. Bu kapsamda sonuçlar, idari personelin kurumla özdeşleşme düzeyinin orta seviyede olduğunu göstermektedir.

Yöneticilerin sorumluluklarını yerine getirmemeleri, çalışanların güven algılamalarını etkilemekte ve değiştirmektedir. Karabük Üniversitesi’nde idari personel olarak çalışmakta olan kişilerin örgütleriyle arasındaki psikolojik sözleşmede algıladıkları ihlalin, örgütlerine karșı hissettikleri güveni ve örgütleriyle kendilerini özdeşleşme derecesini nasıl etkilediğini belirlemek için regresyon analizi yapılmıştır. $\mathrm{Bu}$ kapsamda araştırmanın birinci hipotezini test edilmiş olup psikolojik sözleşme ihlal algısının örgütsel güven üzerinde olumsuz yönde etkide bulunduğu tespit edilmiştir. Başka bir deyişle, idari personelin örgütüyle arasındaki psikolojik sözleşmede algıladığı ihlalin artmasının, örgüte karşı hissedilen güven derecesini azalttığı belirlenmiştir. Psikolojik sözleşme ve güven arasında tespit edilen bu ilişki daha önce yapılan çalışmalardaki sonuçlarla uyumlu çıkmıştır. (Robinson ve Rousseau, 1994; Morrison ve Robinson, 1997). Daha önceki çalışmalardan da anlaşılacağı üzere örgütsel güven ve psikolojik sözleşme ihlali arasında sıkı bir ilişki vardır. Son yıllarda birçok ülkede, devlet kurumlarına duyulan güven gözle görülür biçimde azalmaktadır. Dolayısıyla ortaya çıkan bu güven açığının kapatılması için kurumların psikolojik sözleşme ihlali algısını iyi yönetmeleri büyük önem taşımaktadır.

Araştırmada ikinci hipotezinin test edilmesi sonucunda; psikolojik sözleşme ihlal algısının örgütsel özdeşleşme üzerinde olumsuz yönde etkide bulunduğu ortaya çıkmıştır. Dolayısıyla idari personelin örgütüyle arasındaki psikolojik sözleşmede algıladığı ihlalin artması durumunda örgütüyle arasında algıladığı özdeşleşme derecesinin azaldığı tespit edilmiştir. Psikolojik sözleşme ihlali algısı ve özdeşleşme arasındaki ilişki literatürdeki benzer çalışmalarla paralellik göstermektedir (Aselage ve Eisenberger, 2003; Topcu, 2015). Çalışmada ulaşılan bu sonuç göstermektedir ki çalışanların, çalışmaları sonucu kurumdan istediklerini alamamaları veya verilen sözlerin yerine getirilmediğini düşünmeleri kuruma karşı olumsuz tutum sergilemelerini doğuracaktır. Bunun sonucu olarak, kurumla özdeşleşmenin aksine ayrılmaların olacağı ve kurumda yaşanan bu olumsuzlukların kurumun diğer paydaşlarını da etkileyeceği söylenebilir.

Özel sektör işletmelerinde olduğu gibi kamu kurumları da belirli bir düzen içerisinde çeşitli amaçları gerçekleştirmek üzere kurulan sosyal yapılardır. Kurumsal yapının etkin bir biçimde çalışmasında ana odak noktası insan kaynağıdır. İnsan kaynağının kuruma karşı göstermiş olduğu tutum ve davranışlar kurumsal amaçlara ulaşmada kilit bir role sahiptir. $\mathrm{Bu}$ nedenle kurumda katılımc1 bir yönetim anlayışını benimsenmesi, çalışanlara verilen sözlerin ve taahhütlerin yerine getirilmesi, yöneticilerin çalışanlara karşı adil ve dürüst olmaları, katılımcıları psikolojik olarak rahatlatacak ve çalışanların kurumlarına güven duymalarını arttırmak yoluyla kurumla özdeşleşmelerini sağlayacaktır.

$\mathrm{Bu}$ çerçevede, üniversite yönetimi insan kaynağını çağdaş yönetim anlayışıyla yönetmelidir. Üniversitede çalışan eski ve yeni personelin kuruma bağlılığını sağlamak için politikalar geliştirilmelidir. Katılımcı yönetim anlayışının uygulandığı bir kurum ortamı oluşturulmalıdır. Üniversite yönetimi, çalışanlarının gözündeki kurumsal imajını ve itibarını belirlemek için belirli aralıklarla ölçümler yapmalıdır. Yapılan ölçümler sonucunda gerekli düzenlemeler yapılmalıdır. Çalışanların verimli çalışabilmesi için güvene dayalı bir ilişkinin kurulması ve verilen sözlerin yerine getirilmesi kurumsal özdeşleşmenin sağlanması açısından büyük önem taşımaktadır. Üniversitenin, öğrenen örgüt olabilmesi için çalışanlarını sürekli öğrenme ve geliştirmeye yöneltecek politikalar geliştirmesi gerekmektedir.

Üniversite ile ilgili yukarıda geliştirilen önerilerin yanı sıra benzer çalışmaların Türkiye'deki diğer üniversitelerde karşılaştırmalı olarak yapılması önerilebilir. Yapılacak çalışmaların, önemli birer kurum olan üniversitelerdeki çalışanlar için yapılacak iyileştirmeler açısından rehber görevi görebileceği düşünülmektedir.

\section{Kaynakça}

Anderson, N., \& Schalk, R. (1998). The Psychological Contract in Retrospect and Prospect. Journal of Organizational Behavior, 19, 637-647.

Argyris, C. (1960). Understanding Organizational Behavior. Oxford, England: Dorsey.

Arslan, M. M. (2009). Perceptions of Technical and Industrial Vocational High School Teachers About Organizational Trust. Journal of Theory and Practice in Education, 5(2), 274-288.

Aselage, J., \& Eisenberger, R. (2003). Perceived Organizational Support and Psychological Contracts: A Theoretical Integration. Journal of Organizational Behavior, 24(5), 491-509.

Asunakutlu, T. (2002). Örgütsel Güvenin Oluşturulmasına İlişkin Unsurlar ve Bir Değerlendirme. Muğla Üniversitesi Sosyal Bilimler Enstitüsü Dergisi, 9, 113.

Bal, P. M., De Lange, A. H., Jansen, P. G. W., \& Van Der Velde, M. E. G. (2008). Psychological Contract Breach and Job Attitudes: A Meta-Analysis of Age 
as a Moderator. Journal of Vocational Behavior, 72(1), 143-158.

Bijlsma, K., \& Koopman, P. (2003). Introduction: Trust within Organisations. Personnel Review, 32(5), $543-$ 555.

Büyüköztürk, Ş. (2016). Sosyal Bilimler Iç̧in Veri Analizi El Kitabı. Ankara: Pegem Akademi Yayınları.

Büyükyılmaz, O. (2013). Akademik Personel Açısından Psikolojik Sözleşme Íhlali ile İşten Ayrlma Niyeti Arasındaki Ilişkilerin Analizi. Doktora Tezi. Zonguldak: Bülent Ecevit Üniversitesi Sosyal Bilimler Enstitüsü.

Büyükyılmaz, O., \& Çakmak, A. F. (2014). İlişkisel ve İşlemsel Psikolojik Sözleşmede Algılanan İhlalin İşten Ayrılma Niyeti ve Algılanan Örgütsel Destek Üzerindeki Etkisi. Ege Akademik Bakış, 14(4), 583596.

Büyükyılmaz, O., \& Fidan, Y. (2017). Algılanan Örgütsel Desteğin Örgütsel Vatandaşlık Davranışı Üzerindeki Etkisinde Örgütsel Güvenin Aracılık Rolü. Business \& Management Studies: An International Journal, $5(3), 500-524$.

Byrne, B. M. (2016). Structural Equation Modeling with AMOS: Basic Concepts, Applications, and Programming. New York: Routledge.

Cihangiroğlu, N., \& Şahin, B. (2010). Organizasyonlarda Önemli Bir Fenomen: Psikolojik Sözleşme. Uluslararası Yönetim İktisat ve İşletme Dergisi, 6(11), 1-16.

Clinton, M. E., \& Guest, D. E. (2014). Psychological Contract Breach and Voluntary Turnover: Testing A Multiple Mediation Model. Journal of Occupational and Organizational Psychology, 87(1), 200-207.

Conway, N., \& Briner, R. B. (2005). Understanding Psychological Contracts at Work: A Critical Evaluation of Theory and Research. New York: Oxford University Press.

Çakmak, A. F., Ofluoğlu, G., \& Büyükyılmaz, O. (2012). İnsan Kaynakları Yöneticisinin Karşı Karşıya Olduğu Yeni Psikososyal Riskler: Psikolojik Sözleşme İhlali, Yaşlanan İşgücü, İş-Özel Yaşam Dengesizliği ve Mobbing (Psikolojik Taciz). Катиİs İş Hukuku ve İktisat Dergisi, 12(3), 53-78.

Deery, S. J., Iverson, R. D., \& Walsh, J. T. (2006). Toward a Better Understanding of Psychological Contract Breach: A Study of Customer Service Employees. Journal of Applied Psychology, 91(1), 166-175.

Demircan, N., \& Ceylan, A. (2003). Örgütsel Güven Kavramı: Nedenleri ve Sonuçları. Yönetim ve Ekonomi Dergisi, 10(2), 139-150.

Demirel, Y. (2008). Örgütsel Güvenin Örgütsel Bağlılık Üzerine Etkisi: Tekstil Sektörü Çalışanlarına Yönelik Bir Araştırma. Celal Bayar Üniversitesi I.I.I.B.F, Yönetim ve Ekonomi Dergisi, 15(2), 179184.
Hair, J. F., Black, W. C., Babin, B. J., \& Anderson, R. E. (2014). Multivariate Data Analysis. Harlow: Pearson New International Edition.

Halis, M., Gökgöz, G. S., \& Yaşar, Ö. (2007). Örgütsel Güvenin Belirleyici Faktörleri ve Bankacılık Sektöründe Bir Uygulama. Manas Sosyal Bilimler Dergisi, 17, 187-205.

Huang, X., \& Van de Vliert, E. (2006). Job Formalization and Cultural Individualism as Barriers to Trust in Management. International Journal of Cross Cultural Management, 6(2), 221-242.

Huff, L., \& Kelley, L. (2003). Levels of Organizational Trust in Individualist versus Collectivist Societies: A Seven-Nation Study. Organization Science, 14(1), 81-90.

Jafri, M. H. (2012). Influence of Psychological Contract Breach on Organizational Citizenship Behaviour and Trust. Psychological Studies, 57(1), 29-36.

Karabey, C. N., \& İşcan, Ö. F. (2007). Örgütsel Özdeşleşme, Örgütsel İmaj ve Örgütsel Vatandaşlık Davranış1 İlişkisi: Bir Uygulama. Atatürk Üniversitesi İktisadi ve İdari Bilimler Dergisi, 21(2), 231-241.

Kickul, J. (2001). When Organizations Break Their Promises: Employee Reactions to Unfair Processes and Treatment. Journal of Business Ethics, 29(4), 289-307.

Kline, R. B. (2016). Principles and Practice of Structural Equation Modeling. New York: The Guilford Press.

Köse, C. G. (2009). Örgütsel Özdeşleşmenin Çalışanların Sürekli Iyileştirme Çabalarına Katkısı: Bir Araştırma. Yüksek Lisans Tezi. İstanbul: İstanbul Üniversitesi Sosyal Bilimler Enstitüsü.

Levinson, H., Price, C. R., Munden, K. J., Mandl, H. J., \& Solley, C. M. (1962). Men, Management, and Mental Health. Cambridge, MA, US: Harvard University Press.

Li, P. P., Bai, Y., \& Xi, Y. (2012). The Contextual Antecedents of Organizational Trust: A Multidimensional Cross-level Analysis. Management and Organization Review, 8(2), 371396.

Mael, F., \& Ashforth, B. E. (1992). Alumni and Their Alma Mater: A Partial Test of the Reformulated Model of Organizational Identification. Journal of Organizational Behavior, 13(2), 103-123.

Meydan, C. H., \& Şeşen, H. (2011). Yapısal Eşitlik Modellemesi: AMOS Uygulamaları. Ankara: Detay Yayıncilik.

Morrison, E. W., \& Robinson, S. L. (1997). When Employees Feel Betrayed: A Model of How Psychological Contract Violation Develops. The Academy of Management Review, 22(1), 226-256.

Neves, P., \& Caetano, A. (2006). Social Exchange Processes in Organizational Change: The Roles of Trust and Control. Journal of Change Management, 6(4), 351-364. 
Nunnally, J. C., \& Bernstein, I. H. (1994). Psychometric Theory. New York: McGraw-Hill Inc.

Nyhan, R. C. (2000). Changing the Paradigm: Trust and its Role in Public Sector Organizations. The American Review of Public Administration, 30(1), s. 87-109.

Özan, M. B., \& Özdemir, T. Y. (2013). İlköğretim Kurumu Öğretmenlerinin Örgütsel Güven Düzeyleri: Nitel Bir Çalışma. Gaziantep Üniversitesi Sosyal Bilimler Dergisi, 12(3), 469-486.

Restubog, S. L. D., Hornsey, M. J., Bordia, P., \& Esposo, S. R. (2008). Effects of Psychological Contract Breach on Organizational Citizenship Behaviour: Insights from the Group Value Model. Journal of Management Studies, 45(8), 1377-1400.

Reychav, I., \& Sharkie, R. (2010). Trust: An Antecedent to Employee Extra-Role Behaviour. Journal of Intellectual Capital, 11(2), 227-247.

Ristig, K. (2009). The Impact of Perceived Organizational Support and Trustworthiness on Trust. Management Research News, 32(7), 659-669.

Robinson, S. L. (1996). Trust and Breach of the Psychological Contract. Administrative Science Quarterly, 41(4), 574-599.

Robinson, S. L., \& Morrison, E. W. (1995). Psychological Contracts and OCB: The Effect of Unfulfilled Obligations on Civic Virtue Behavior. Journal of Organizational Behavior, 16(3), 289-298.

Robinson, S. L., \& Morrison, E. W. (2000). The Development of Psychological Contract Breach and Violation: A Longitudinal Study. Journal of Organizational Behavior, 21(5), 525-546.

Robinson, S. L., \& Rousseau, D. M. (1994). Violating the Psychological Contract: Not the Exception but the Norm. Journal of Organizational Behavior, 15(3), 245-259.

Rousseau, D. M. (1989). Psychological and Implied Contracts in Organizations. Employee Responsibilities and Rights Journal, 2(2), 121-139.

Rousseau, D. M. (1995). Psychological Contracts in Organizations: Understanding Written and Unwritten Agreements. Thousand Oaks: Sage Publications, Inc.

Schumacker, R. E., \& Lomax, R. G. (2010). A Beginner's Guide to Structural Equation Modeling. New York: Routledge.

Sekaran, U., \& Bougie, R. (2016). Research Methods for Business A Skill-Building Approach. Chichester: Wiley.

Shore, L. M., \& Tetrick, L. E. (1994). The Psychological Contract as an Explanatory Framework in the Employment Relationship. İçinde: Trends in Organizational Behavior, Vol. 1. Oxford, England: John Wiley \& Sons, 91-109.

Şakar, A. N. (2010). Örgütsel Güven. İçinde: Ergun Özler, E. (Ed.), Örgütsel Davranışta Güncel Konular, Bursa: Ekin Yayınevi, 21-40.
Tokgöz, E., \& Seymen, O. A. (2013). Örgütsel Güven, Örgütsel Özdeşleşme ve Örgütsel Vatandaşlık Davranışı Arasındaki İlişki: Bir Devlet Hastanesinde Araştırma. Öneri Dergisi, 10(39), 61-76.

Topcu, M. K. (2015). Çalışanların Kişilik Özelliklerinin Örgütsel Özdeşleşme ve Işsten Ayrllma Niyeti Üzerine Etkisinde Psikolojik Sözleşme Algisinın Rolü. Doktora Tezi. Ankara: Kara Harp Okulu Savunma Bilimleri Enstitüsü.

Tufan, P., \& Wendt, H. (2020). Organizational Identification as a Mediator for the Effects of Psychological Contract Breaches on Organizational Citizenship Behavior: Insights from the Perspective of Ethnic Minority Employees. European Management Journal, 38(1), 179-190.

Turnley, W. H., \& Feldman, D. C. (2000). Re-Examining the Effects of Psychological Contract Violations: Unmet Expectations and Job Dissatisfaction as Mediators. Journal of Organizational Behavior, 21(1), 25-42.

Turunç, Ö., \& Çelik, M. (2010). Çalışanların Algıladıkları Örgütsel Destek ve İş Stresinin Örgütsel Özdeşleşme ve İş Performansına Etkisi. Yönetim ve Ekonomi Dergisi, 17(2), 183-206.

Uyar, B., \& Güneş Z. (2019). Ortaokullarda Örgütsel Sinizmin Yordayıcısı Olarak Örgütsel Güven. Anemon Muş Alparslan Üniversitesi Sosyal Bilimler Dergisi, 7(3), 121-128.

Üstün, F. (2015). Örgütlerde Sikılık-Esneklik Boyutunun Örgütsel Güven, Kurumsal Girişimcilik ve Firma Performansina Etkisi: Türkiye'nin Öncü Sanayi İşletmeleri Üzerine Bir Araştırma. Doktora Tezi. Adana: Çukurova Üniversitesi, Sosyal Bilimler Enstitüsü.

van Gilst, E., Schalk, R., Kluijtmans, T., \& Poell, R. (2020). The Role of Remediation in Mitigating the Negative Consequences of Psychological Contract Breach: A Qualitative Study in the Banking Sector. Journal of Change Management, 1-19.

Yang, W., \& Chao, L. (2016). How Psychological Contract Breach Influences Organizational Identification and Organizational Citizenship Behavior: The Mediating Role of Psychological Capital. American Journal of Industrial and Business Management, 6, 922-930.

Yıldız, T., \& Aykanat, Z. (2017). Psikolojik Sözleşme Kavramının Evrimsel Gelişiminin Bilimsel Haritalama Yöntemiyle İncelenmesi. Yönetim Bilimleri Dergisi, 15(29), 243-263.

Zagenczyk, T. J., Cruz, K. S., Woodard, A. M., Walker, J. C., Few, W. T., Kiazad, K., \& Raja, M. (2013). The Moderating Effect of Machiavellianism on the Psychological Contract Breach Organizational Identification Disidentification Relationships. Journal of Business and Psychology, 28(3), 287-299. 